\title{
A clinico-bacteriological study of lacrimal regurgitate in cases of chronic dacryocystitis in a referral hospital in Madhya Pradesh
}

\section{Devendra Kumar Shakya, Shashi Gandhi', Neha Adlakha, Rashmi Kujur, Harsh Raj Singh Chauhan, K. P. Ranjan 1}

Departments of Ophthalmology and ${ }^{1}$ Microbiology, Gajra Raja Medical College, Gwalior, Madhya Pradesh, India

Address for the Correspondence:

Dr. Neha Adlakha, House No. 1544, Sector-7 Extension, Gurgaon, Haryana, India.

E-mail: neha.adlakha777@ gmail.com

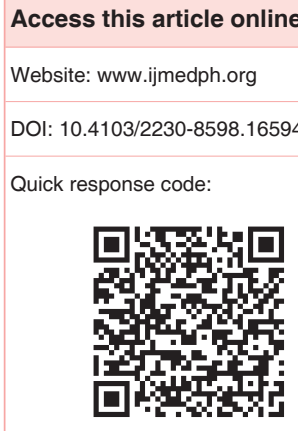

Background: Chronic dacryocystitis is an inflammation of the lacrimal sac which usually occurs because of the obstruction of the nasolacrimal duct. Objective: The primary objective of the study was to know its clinico-bacteriological profile. Materials and Methods: This prospective observational study was carried out over a period of one year to know the current bacterial flora involved in chronic dacryocystitis. All specimens were processed for isolation and identification of bacterial pathogens according to the standard microbiological techniques. The antibiotic susceptibility pattern was done by Kirby-Bauer disc diffusion method according to the Clinical Laboratory Standards Institute guidelines. Results: Among total 100 cases of chronic dacryocystitis, the highest percentage of infections in relation to age was noted in the age group of 50-60 years and the prevalence rate was higher in female patients compared with male. Out of total chronic dacryocystitis cases, $72 \%$ cases were found to be culture positive. Among positive culture, gram positive organisms were higher than that of Gram-negative. Staphylococcus epidermidis was the most frequently isolated and Streptococcus pyogenes was least isolated. The highest percentage of positive samples was found in the mucopurulent discharge followed by extensive purulent and clear fluid, respectively. In Grampositive isolates, chloramphenicol was the most sensitive followed by cefazolin, ciprofloxacin, ofloxacin, cephalexin, vancomycin, gentamycin, and tobramycin, respectively, whereas in Gram-negative isolate, chloramphenicol and nalidixic acid were equally effective followed by ofloxacin, gentamycin, cephalexin, cefazolin and ciprofloxacin, respectively. Conclusion: S. epidermidis was the most frequently isolated bacteria, and chloramphenicol was the most susceptible drug in Gram-positive and Gram-negative bacteria.

Key words: Chronic dacryocystitis, clinico-bacteriological profile, lacrimal regurgitate

\section{INTRODUCTION}

Chronic dacryocystitis is an inflammation of the lacrimal sac which usually occurs because of the obstruction of the nasolacrimal duct. The obstruction may be an idiopathic inflammatory stenosis (primary acquired nasolacrimal duct obstruction) ${ }^{[1]}$ or may be secondary to trauma, inflammation, neoplasm, or mechanical obstruction (secondary acquired lacrimal drainage obstruction). ${ }^{[2]}$ Obstruction of the nasolacrimal duct from whatever source results in stasis with the accumulation of tears, desquamated cells, and mucoid secretions superior to the obstruction in a pathologically closed lacrimal drainage system. This creates a fertile environment for secondary bacterial infection and can

This is an open access article distributed under the terms of the Creative Commons AttributionNonCommercial-ShareAlike 3.0 License, which allows others to remix, tweak, and build upon the work non-commercially, as long as the author is credited and the new creations are licensed under the identical terms.

For reprints contact: reprints@medknow.com

How to cite this article: Shakya DK, Gandhi S, Adlakha N, Kujur R, Singh Chauhan HR, Ranjan KP. A clinico-bacteriological study of lacrimal regurgitate in cases of chronic dacryocystitis in a referral hospital in Madhya Pradesh. Int J Med Public Health 2015;5:270-3. 
result in dacryocystitis which is a constant threat to the cornea and orbital soft tissue..$^{[3]}$ It is an important cause of ocular morbidity in India. It is the most common cause of epiphora and may present with or without mucopurulent discharge..$^{[4]}$ Chronic dacryocystitis is an ancient disease, and several studies have been done to know its microbiological profile. The studies have shown that bacterial pathogens differ in chronic and acute dacryocystitis. ${ }^{[5]}$ Bacterial species isolated from chronic dacryocystitis shows higher resistance to broad spectrum antibiotics than acute dacryocystitis which may be the potential pathogens in postoperative infections, both in intraocular and lacrimal drainage surgeries. ${ }^{[6]}$ There are distinct patterns of geographical variation in terms of etiology. Hence, an understanding of the regional etiological agents is important in the management of this disease. The knowledge of bacteriology of chronic dacryocystitis would contribute to the choice of effective antimicrobial agents and would help to reduce the unnecessary load of antimicrobial agents and development of drug resistance. This study is to know the current bacterial flora involved in chronic dacryocystitis so that proper antimicrobial prophylaxis can be planned.

\section{MATERIALS AND METHODS}

This prospective study was undertaken in the Department of Ophthalmology in collaboration with the Department of Microbiology, Gajra Raja Medical College, Gwalior. All the specimens were received from the outpatients of the Department of Ophthalmology, J.A. Group of Hospitals of Gajra Raja Medical College, Gwalior from October 2012 to September 2013. This research work was executed after approval from the Ethical Committee. Patients were recorded in a predesigned proforma, including the detailed history and relevant examination and were informed about the procedure, and a written consent was taken. Samples were collected from all the cases under complete aseptic precautions using sterile swab stick tube and were subjected to culture and antibiotic susceptibility testing. In all cases, routine diagnostic tests were done on the $1^{\text {st }}$ day. On the same day, regurgitated material was collected for bacteriological examination. The specimen of regurgitate material inoculated on blood agar, MacConkey agar, and glucose broth which were aerobically incubated for $24 \mathrm{~h}$ at $37^{\circ} \mathrm{C}$. Subcultures from the liquid media onto solid media were carried out after incubating for 18-24 h. The plates were read the following day but extended to $48 \mathrm{~h}$ if there was no bacterial growth within 24 h. Isolated colonies were subjected to identification by colony morphology, gram staining, and standard biochemical tests. ${ }^{[7]}$ The antibiotic susceptibility pattern was done by Kirby-Bauer disc diffusion method according to the Clinical Laboratory Standards Institute guidelines. ${ }^{[8]}$

\section{RESULTS}

A total of 100 cases of chronic dacryocystitis were included in the study. The highest percentage of infections in relation to age were noted in the age group of $50-60$ years $(25 \%), 60-70$ years $(18 \%)$,
$20-30$ years $(17 \%), 30-40$ years $(17 \%), 40-50$ years $(12 \%)$, more than 70 years $(6 \%)$, and $10-20$ years $(5 \%)$ [Table 1$]$. We also found the relationship between chronic dacryocystitis infections and sex. The prevalence rate was higher in female $(81 \%)$ patients compared with male (19\%). Females and male ratio was found to be 4:1. Past history of exanthematous fever followed by epiphora was obtained in $28 \%$ cases of chronic dacryocystitis. In the most cases, more than one etiological factor were found. The most common factor found in 65\% of cases was nasal and sinus infection (rhinitis/ sinusitis) followed by exposure to heat and dust in 35\% and past history of chicken pox in $28 \%$. Nasal diseases were commonly found associated with chronic dacryocystitis. Hypertrophied inferior turbinate was found in $41 \%$ cases, deviated nasal septum in $49 \%$ of cases, and rhinitis was found in $10 \%$ cases of chronic dacryocystitis. Out of 100 cases, $72(72 \%)$ samples showed positive growth. The growth of Gram-positive organisms (88.08\%) was higher than that of Gram-negative (11.90\%). Single growth of organisms $(73.81 \%)$ was higher than mixed growth $(26.19 \%)$. Single to mixed growth ratio was found to be 6.2:1. Staphylococcus epidermidis (38.88\%) was the most frequently isolated organisms, and Streptococcus pyogenes was least $(1.38 \%)$ commonly isolated [Table 3]. There was significant growth of $S$. epidermidis among all isolates $(P=0.018)$. Staphylococcus aureus was found most commonly isolated organism in mixed growth, followed by Streptococcus pneumoniae, and S. epidermidis were rarely found in mixed growth [Table 2]. The highest percentage of positive samples was found in the mucopurulent discharge $(46.43 \%)$, followed by extensive purulent (41.67\%) and the lowest was in the clear fluid (11.90\%). In Gram-positive isolates, chloramphenicol was the most sensitive

\begin{tabular}{|c|c|c|c|}
\hline Age group (years) & Male $n(\%)$ & Female $n(\%)$ & Total $n(\%)$ \\
\hline $10-20$ & $2(2)$ & $3(3)$ & $05(05)$ \\
\hline $20-30$ & $4(4)$ & $13(13)$ & $17(17)$ \\
\hline $30-40$ & $4(4)$ & $13(13)$ & $17(17)$ \\
\hline $40-50$ & $0(0)$ & $12(12)$ & $12(12)$ \\
\hline $50-60$ & $5(5)$ & $20(20)$ & $25(25)$ \\
\hline $60-70$ & $2(2)$ & $16(16)$ & $18(18)$ \\
\hline$>70$ & $2(2)$ & $04(04)$ & $06(06)$ \\
\hline Total & $19(19)$ & $81(81)$ & $100(100)$ \\
\hline
\end{tabular}

\begin{tabular}{|c|c|c|}
\hline Organism isolated in growth & $\begin{array}{c}\text { Number of } \\
\text { organism in } \\
\text { single growth } \\
(\%)\end{array}$ & $\begin{array}{c}\text { Number of } \\
\text { organism in } \\
\text { mixed growth } \\
(\%)\end{array}$ \\
\hline Staphylococcus epidermidis & $28(45.16)$ & $01(4.54)$ \\
\hline Staphylococcus aureus & $13(20.96)$ & $08(36.36)$ \\
\hline Streptococcus pneumoniae & $12(19.35)$ & $05(22.72)$ \\
\hline Streptococcus pyogenes & $01(1.61)$ & $02(9.09)$ \\
\hline Streptococcus viridians & $03(4.84)$ & $01(4.54)$ \\
\hline Escherichia coli & $03(4.84)$ & $03(13.63)$ \\
\hline Hemophilus influenzae & $02(3.23)$ & $02(9.09)$ \\
\hline
\end{tabular}


drug (95.94\%), followed by cefazolin (94.59\%), ciprofloxacin and ofloxacin (92.34\%), cephalexin (90.54\%), vancomycin $(85.13 \%)$, gentamycin $(74.32 \%)$, and tobramycin $(52.70 \%)$ [Table 4$]$. In Gram-negative isolate, chloramphenicol and nalidixic acid were the maximally effective followed by ofloxacin, gentamycin, cephalexin, cefazolin, and ciprofloxacin [Table 5].

\section{DISCUSSION}

The most common inflammation of the lacrimal apparatus is dacryocystitis. The lacrimal system is prone to infection and inflammation for various reasons. This mucous membrane-lined tract is contiguous with two surfaces (conjunctival and nasal mucosa) that are normally colonized with bacteria. The functional purpose of the lacrimal excretory system is to drain tears from the eye into the nasal cavity. Obstruction of the nasolacrimal duct from whatever source results in stasis with accumulation of tears, desquamated cells, and mucoid secretions superior to the obstruction. This creates a fertile environment for secondary bacterial infection. Chronic dacryocystitis is significantly more common in the age above 30 years. Dacryocystitis, as a disease entity, is known since ancient times. It is an important cause of ocular morbidity, both in children and adults. Hence, it requires special attention with respect to the initiation of the appropriate treatment at the earliest. The pattern of the relative incidence of various factors varies in different studies and inflammation of lacrimal sac has been known from early times due to its invariable tendency to produce cosmetic defects on the face. The chronicity was characterized by remissions and relapses and its unpredictable response to therapy form the outstanding features of the disease. The etiology of chronic dacryocystitis, though extensively

\begin{tabular}{|c|c|}
\hline Organism & Number of cases $(\%)$ \\
\hline Staphylococcus epidermidis & $28(38.88)$ \\
\hline Staphylococcus aureus & $13(18.55)$ \\
\hline Streptococcus pneumoniae & $12(16.66)$ \\
\hline Streptococcus viridians & $3(4.16)$ \\
\hline Escherichia coli & $3(4.16)$ \\
\hline Hemophilus influenzae & $2(2.76)$ \\
\hline Streptococcus pyogenes & $1(1.38)$ \\
\hline
\end{tabular}

studied, is not yet fully understood. The multiplicity of etiological factors and the more or less similar histological response indicates a nonspecific nature of the disease. Normally, the lacrimal sac and the nasolacrimal duct comprise one continuous functioning tube. This tube is lined by delicate mucosa which is constantly exposed to infection. The lower end of this tube, that is, the nasal duct is, especially vulnerable. In the present study, it was observed that the maximum numbers of dacryocystitis cases were found to be most common (54\%) between 30 and 60 years of age. Our results were consistent with similar studies carried out by Diggle, Duke-Elder and MacFaul, and Reddy and Reddy, which showed maximum incidence in 35-65 years. ${ }^{[9-11]}$ The incidence of disease was found to be more common in females $(81 \%)$. Worldwide, chronic dacryocystitis has been reported to be much more common in females than males, having a sex ratio of 3.99:1. ${ }^{[6]}$ Our results were consistent with similar studies carried out by Mallik and Chatterjee ${ }^{[12]}$ which showed female preponderance in $71.2 \%$. The various reasons have been put forward to explain this preponderance such as excessive lacrimation in females, long stay in the kitchen with consequent greater exposure to soot, smoke, and heat. However, the anatomical factor of the narrow bony nasolacrimal canal appears to be more acceptable. In the present study, $65 \%$ of cases of chronic dacryocystitis found to have nasal and sinus infection which is in agreement with most of the workers. ${ }^{[13,14]}$ Inferior turbinate was found in $41 \%$ of cases and rhinitis was found in $10 \%$ cases of dacryocystitis. Our study shows that positive growth was found in $72 \%$ of the specimen. Results were consistent with similar studies carried out by Chaudhary et al. and Bharathi et al. which showed positive growth in $79.80 \%$ and $80.30 \% \cdot{ }^{[6,15]}$ Gram-positive $(88.10 \%)$ bacteria isolated more than Gram-negative $(11.90 \%)$ bacteria. Bharathi et al., Coden et al. and Hartikainen et al. reported 69.7\%, 65\%, and $69 \%$ of Gram-positive cocci, respectively. ${ }^{[5,6,16]}$ Single growth of organisms is more common than mixed growth $(26.19 \%)$. Microbiological study revealed that $S$. epidermidis (38.88\%) were the most commonly isolated followed by $S$. aureus (18.55\%) which is almost similar to study by Coden $e t$ al. which showed $S$. aureus in $27.3 \%{ }^{[16]} S$. aureus was the most predominant bacteria in mixed growth following, Streptococcus pneumoniae, and S. epidermidis rarely found in mixed growth. These findings are in accordance with those of Bharathi et al. ${ }^{[6]}$ and Brook et al. ${ }^{[17]}$ Out of 74 Grampositive isolates, chloramphenicol was the most susceptible

\begin{tabular}{lccccc} 
Table 4: Antibiotic sensitivity pattern among gram-positive isolates \\
\hline Antibiotics & \multicolumn{5}{c}{ Susceptibility of microorganisms } \\
\cline { 2 - 6 } & $\begin{array}{c}\text { Staphylococcus } \\
\text { epidermidis (\%) }\end{array}$ & $\begin{array}{c}\text { Staphylococcus } \\
\text { aureus (\%) }\end{array}$ & $\begin{array}{c}\text { Streptococcus } \\
\text { pneumoniae (\%) }\end{array}$ & $\begin{array}{c}\text { Streptococcus } \\
\text { pyogenes (\%) }\end{array}$ & $\begin{array}{c}\text { Streptococcus } \\
\text { viridians (\%) }\end{array}$ \\
\hline Chloramphenicol & $29(100)$ & $18(85.71)$ & $17(100)$ & $03(100)$ & $04(100)$ \\
Gentamycin & $27(93.10)$ & $07(33.33)$ & $16(94.1)$ & $02(66.66)$ & $03(75)$ \\
Ciprofloxacin & $28(96.50)$ & $18(85.71)$ & $17(100)$ & $02(66.66)$ & $04(100)$ \\
Ofloxacin & $28(96.50)$ & $18(85.71)$ & $17(100)$ & $02(66.66)$ & $04(100)$ \\
Cefazolin & $27(93.10)$ & $20(95.23)$ & $17(100)$ & $03(100)$ & $03(75)$ \\
Cephalexin & $27(91.10)$ & $18(85.71)$ & $16(94.11)$ & $03(100)$ & $03(75)$ \\
Tobramycin & $14(48.27)$ & $11(52.38)$ & $09(52.94)$ & $02(66.66)$ & $03(75)$ \\
\hline
\end{tabular}




\begin{tabular}{lcc}
$\begin{array}{l}\text { Table 5: Antibiotic sensitivity pattern among } \\
\text { gram-negative isolates }\end{array}$ \\
\hline Antibiotics & Susceptibility of microorganisms \\
\cline { 2 - 3 } & $\begin{array}{c}\text { Escherichia coli } \\
(\%)\end{array}$ & $\begin{array}{c}\text { Hemophilus influenzae } \\
(\%)\end{array}$ \\
\hline Chloramphenicol & $06(100)$ & $03(75)$ \\
Gentamycin & $05(83.33)$ & $02(50)$ \\
Ciprofloxacin & $04(66.66)$ & $01(25)$ \\
Ofloxacin & $04(66.66)$ & $03(75)$ \\
Cefazolin & $04(66.66)$ & $02(50)$ \\
Cephalexin & $04(66.66)$ & $02(50)$ \\
Nalidixic acid & $05(83.33)$ & $04(100)$ \\
\hline
\end{tabular}

drug (95.94\%), followed by cefazolin $(94.59 \%)$ and out of 10 , Gram-negative isolates, chloramphenicol, and cefazolin were most susceptible, and ciprofloxacin was the least susceptible to Gram-negative isolates. These findings are in accordance with those of Chaudhary et al. ${ }^{[15]}$

\section{CONCLUSION}

The frequency of isolation of Gram-positive organisms was higher than that of Gram-negative organisms. S. epidermidis was the most frequently isolated bacteria among all isolates, and $S$. pyogenes was the most predominant bacteria in mixed growth. In Gram-positive isolates, chloramphenicol was the most susceptible drug, followed by cefazolin and among Gramnegative isolates, chloramphenicol and cefazolin were most susceptible, whereas ciprofloxacin was the least susceptible to Gram-negative isolates.

\section{Financial support and sponsorship}

Nil.

\section{Conflicts of interest}

There are no conflicts of interest.

\section{REFERENCES}

1. Linberg JV, McCormick SA. Primary acquired nasolacrimal duct obstruction. A clinicopathologic report and biopsy technique. Ophthalmology 1986;93:1055-63.

2. Bartley GB. Acquired lacrimal drainage obstruction: An etiologic classification system, case reports, and a review of the literature. Part 1. Ophthal Plast Reconstr Surg 1992;8:237-42.

3. Iliff NT. Infections of the lacrimal drainage system. In: Peopse JS, Holland GN, Wilhelmus KR, editors. Ocular Infection and Immunity. St. Louis, MO: Mosby; 2010. p. 1346-55.

4. Jacobs HB. Symptomatic epiphora. Br J Ophthalmol 1959;43:415-34.

5. Hartikainen J, Lehtonen OP, Saari KM. Bacteriology of lacrimal duct obstruction in adults. Br J Ophthalmol 1997;81:37-40.

6. Bharathi MJ, Ramakrishnan R, Maneksha V, Shivakumar C, Nithya V, Mittal S. Comparative bacteriology of acute and chronic dacryocystitis. Eye 2008;22:953-60.

7. Baird D. Staphyloccus: Cluster-forming Gram-positive cocci. In: Collee JG, Fraser AG, Marmion BP, Simmons A, editors. Mackie \& MacCartney Practical Medical Microbiology. $14^{\text {th }}$ ed. New York: Churchill Livingstone; 1996. p. 245-61.

8. Central Laboratory Standards Institute (CLSI). Performance standards for antimicrobial disc susceptibility tests, approved standards. CLSI Document M02-A10. 10 ${ }^{\text {th }}$ ed., Vol. 29. No-1: Central Laboratory Standards Institute; 2010.

9. Diggle $\mathrm{FH}$. Lacrymal obstruction: Its nasal origin and intranasal treatment. Br Med J 1927;2:933-5.

10. Duke-Elder S, MacFaul PA. Diseases of the lacrimal passages. System of Ophthalmology. St. Louis: CV Mosby; 1974. p. 674-770.

11. Reddy S, Reddy B. A clinicopathological study of chronic dacryocystitis. JAMA 1955;24:413.

12. Mallik SR, Chatterjee DL. Dacryocystography of normal and disturbed lacrimal passage. Orient Arch Ophthalmol 1970;8:5.

13. Bale RN. Dacryocystitis: Bacteriological study and its relation with nasal pathology. Indian J Ophthalmol 1987;35:178-82.

14. Bhale RN. Dacryocystitis: Bacteriological study and its relation with nasal pathology. Indian J Ophthalmol 1988;35:178-82.

15. Chaudhary M, Bhattarai A, Adhikari SK, Bhatta DR. Bacteriology and antimicrobial susceptibility of adult chronic dacryocystitis. Nepal J Ophthalmol 2010;2:105-13.

16. Coden DJ, Hornblass A, Haas BD. Clinical bacteriology of dacryocystitis in adults. Ophthal Plast Reconstr Surg 1993;9:125-31.

17. Brook I, Frazier EH. Aerobic and anaerobic microbiology of dacryocystitis. Am J Ophthalmol 1998;125:552-4. 